\title{
PERAN KEPALA KUA \\ DALAM MEMBANGUN MODERASI BERAGAMA DI KABUPATEN MAJALENGKA
}

\author{
Agus Susanto \\ KUA Kecamatan Cingambul Kabupaten Majalengka, Jawa Barat \\ Email: agussusantopenghulu@gmail.com
}

\begin{tabular}{l} 
doi) https://doi.org/10.36052/andragogi.v7i2.92 \\
Diterima: 9 Oktober 2019 | Disetujui: 2 Desember 2019 | Dipublikasikan: 30 Desember 2019 \\
\hline
\end{tabular}

\begin{abstract}
Abstrak
Tujuan penelitian ini adalah untuk menentukan berbagai alternatif strategis dengan memaksimalkan peran Kepala KUA dalam membangun moderasi beragama di Kabupaten Majalengka. Penelitian ini menggunakan metode penelitian campuran (mixed methodology), metode yang memadukan pendekatan kualitatif dan kuantitatif dan menggunakan analisis SWOT sebagai pisau analisis untuk mengkaji faktor-faktor internal dan faktor-faktor eksternal yang mempengaruhi kepala KUA dalam membangun moderasi beragama di Kabupaten Majalengka. Berdasarkan hasil IFAS-EFAS, diketahui bahwa peran kepala KUA dalam membangun moderasi beragama di Kabupaten Majalengka sudah relatif baik dan harus dipertahankan karena mempunyai potensi yang sangat besar untuk kemaslahatan publik. Keberadaan faktor-faktor internal dan eksternal pada dasarnya menjadi dukungan yang sangat besar bagi peran kepala KUA.
\end{abstract}

Kata Kunci: Peran kepala KUA, moderasi beragama, analisis SWOT

\begin{abstract}
This study is aimed to determine several strategic alternatives by maximizing the role of the chief of KUA in developing religious moderation in Majalengka Regency. In this study, the author used a mixed methodology, a method that combines qualitative and quantitative approaches and uses a SWOT analysis as a knife analysis to examine internal and external factors that influence the chief of KUA in building religious moderation in Majalengka Regency. Based on the results of IFAS-EFAS, it is discovered that the role of the chief of KUA in developing religious moderation in Majalengka Regency is relatively good and must be maintained because it has enormous potential for public benefit. The existing internal and external factors basically becomes a big support for the role of the chief of KUA.
\end{abstract}

Keywords: role of chief of KUA, religious moderation, SWOT analysis 


\section{PENDAHULUAN}

$\mathcal{P}$

Pluralitas adalah eksistensi yang diakui sebagai sunnat Allah. Pluralitas tersebut terdapat pada hampir semua masyarakat, baik etnis, suku, bahasa, ras, kebudayaan, maupun agama. Tak ada masyarakat yang benar-benar sama atau homogen. Artinya tiap masyarakat itu berbeda meskipun perbedaan itu beragam sesuai dengan tingkatannya (Athorida, 2010:115).

Berkenaan dengan perbedaan agama, para pemerhati masalah keagamaan menganalisa bahwa ketegangan antar agama diakibatkan oleh pola fikir setiap agama (religions way of knowing) yang mengklaim dirinya sebagai kebenaran (claim of truth) dan jalan keselamatan (claim of salvation). Keadaan ini "diperparah" dengan ajaran untuk menyelamatkan seluruh umat manusia dengan memeluk agama yang diyakini kebenarannya itu. Dampaknya, orang-orang tertentu menganggap bahwa dirinyalah yang benar dan-bahkan-merasa berhak dan berkewajiban "meluruskan" orangorang yang tidak sepaham. Pada tingkat yang lebih intern, keadaan serupa juga terjadi seperti konflik perbedaan mazhab dan lain-lain (Rasyid, 2009:423). Karena cara pandang setiap agama yang demikian, selalu ada potensi pergesekan antar agama atau antar pemeluk agama yang sama. Dalam hal ini, agama bermata ganda; agama memiliki kekuatan untuk membuat kehidupan menjadi tentram, namun ia juga berpotensi besar menjadi biang konflik seperti intoleransi, radikalisme, bahkan terorisme yang menumpahkan darah manusia.

Potensi konflik antar agama dan antar pemeluk agama bisa saja terjadi di
Kabupaten Majalengka, mengingat penduduk yang tinggal di Kabupaten Majalengka tidak homogen. Dengan jumlah kecamatan yang ada di Kabupaten Majalengka sebanyak 26 kecamatan, penduduk yang memeluk agama Islam berjumlah 1.211 .072 orang (99,641\%); yang memeluk agama Kristen berjumlah 3.547 orang (0,291\%); yang memeluk agama Katholik berjumlah 579 orang $(0,047 \%)$; yang memeluk agama Hindu berjumlah 56 orang $(0,004 \%)$; yang memeluk agama Budha berjumlah 166 orang $(0,013 \%)$; dan yang memeluk agama Konghucu berjumlah 12 orang $(0,001)$. Adapun jumlah sarana peribadatan yang tersebar di kabupaten Majalengka adalah mesjid berjumlah 1.083 buah; langgar berjumlah 4.982 buah; mushalla berjumlah 841 buah; gereja berjumlah 12 buah; pura berjumlah 1 buah, dan; vihara berjumlah 3 buah.

Para pemerhati masalah keagamaan memandang perlu merumuskan dan mengembangkan konsep, teori, dan agenda aksi untuk meredam konflik agama sebab, dalam realitas kehidupan nyata, manusia tidak dapat menghindarkan diri dari perkaraperkara yang berseberangan dalam masalah agama. Salah satu cara yang dibutuhkan untuk menjembatani perbedaan agama adalah sikap moderat dalam beragama. Dalam hal yang disebut terakhir, kepala KUA memiliki peran dalam pembangunan moderasi beragama.

Kepala KUA dapat melakukan dua pendekatan sekaligus, yakni pendekatan penegakan hukum dan pendekatan persuasif. Pendekatan hukum dapat dilakukan mengingat kepala KUA dalam melaksanakan tugasnya harus berpijak pada peraturan perundang-undangan yang berlaku, sedangkan pendekatan 
persuasif dapat dilakukan melalui upayaupaya sosialisasi dimana kepala KUA sering tampil di tengah-tengah masyarakat, baik secara personal maupun institusional.

Untuk mengkaji peran Kepala KUA dalam membangun moderasi beragama maka dapat digunakan analisis SWOT, sebuah alat analisis tradisional yang mengintegrasikan perspektif internal dengan eksternal. Analisis SWOT ini merupakan metode analisis yang paling dasar untuk melihat suatu topik atau permasalahan dari empat sisi yang berbeda guna mendapatkan gambaran secara singkat, tepat, dan cepat mengenai keadaan stratejik organisasi (Assauri, 2016:71). Hasil analisis ini berupa arahan/rekomendasi untuk mempertahankan kekuatan dan menambah keuntungan dari peluang yang ada, dengan mengurangi kekurangan dan menghindari ancaman. Jika digunakan dengan benar, analisis SWOT akan membantu untuk melihat sisi-sisi yang terlupakan atau tidak terlihat (Yusuf, 2016:110).

Dengan demikian, tujuan penelitian ini adalah untuk mengetahui analisis SWOT terhadap peran kepala KUA dalam membangun moderasi beragama di Kabupaten Majalengka.

\section{METODE PENELITIAN}

Metode penelitian yang penulis gunakan adalah jenis penelitian campuran (mixed methodology), metode yang memadukan pendekatan kualitatif dan kuantitatif. Metode ini menghasilkan fakta yang lebih komprehensif dalam meneliti masalah penelitian. Peneliti memiliki kebebasan untuk menggunakan semua alat pengumpul data sesuai dengan jenis data yang dibutuhkan sebab kualitatif dan kuantitatif hanya sebatas pada jenis alat pengumpul data tertentu saja. Dengan demikian, jenis penelitian campuran ini dapat menyatukan data kualitatif dan data kuantitatif agar memperoleh analisis yang lebih lengkap.

Dalam penelitian ini, penulis menggunakan analisis SWOT sebagai pisau analisis untuk mengkaji faktorfaktor internal dan faktor-faktor eksternal yang mempengaruhi kepala KUA dalam membangun moderasi beragama di Kabupaten Majalengka.

\section{Peran Kepala KUA}

Kepala KUA Kecamatan adalah penghulu yang diberi tugas tambahan sebagai Kepala KUA Kecamatan. Dengan demikian, kepala KUA adalah penghulu secara personal namun memiliki tugas jabatan secara institusional. Peran-peran yang dimiliki oleh seorang kepala KUA adalah sebagai berikut:

1. Kepala KUA memiliki tugas-tugas pokok sebagai penghulu seperti melakukan pengawasan nikah/rujuk menurut agama Islam dan kegiatan kepenghuluan meliputi pengkajian masalah hukum munakahat, bahthul masā'il munakahat dan ahwāl alshakhshiyah.

2. Kepala KUA memiliki tugas-tugas pokok antara lain menyelenggarakan fungsi pelaksanaan nikah dan rujuk; bimbingan keluarga sakinah; bimbingan kemasjidan; bimbingan pembinaan syariah; serta menyelenggarakan fungsi lain di bidang agama Islam yang ditugaskan oleh Kepala Kantor Kementerian Agama Kabupaten/Kota.

3. Selain sebagai kepala kantor, kepala KUA berperan sebagai manajer yang memiliki empat peran sekaligus (Handjoko, 2009:9), yakni: 
a. Peran kepala KUA sebagai wakil pemerintah; Peran wakil Pemerintah dilakukan oleh kepala KUA ketika pegawai atau karyawan KUA dan masyarakat umum membutuhkan klarifikasi dan petunjuk yang berhubungan langsung dengan pekerjaan. Dalam hal ini, kepala KUA berdiri pada posisi Pemerintah.

b. Peran kepala KUA sebagai komandan; Peran komandan ini dilakukan kepala KUA dalam rangka memimpin, mengorganisasikan, melaksanakan dan melaporkan pelaksanaan tugas.

c. Peran kepala KUA sebagai guru; Peran guru bertujuan untuk memperkuat karyawan KUA lebih terampil menjalankan tugas dan lebih kokoh mempertahankan kinerja KUA.

d. Peran kepala KUA sebagai bapak; Peran ini dilakukan kepala KUA untuk menangani aspek manusiawi pegawai atau karyawan KUA seperti memberi nasihat, memberi perlindungan, menangani pertikaian, dan sebagainya.

4. Kepala KUA berperan sebagai fasilitator bimbingan perkawinan pranikah. Di antara kepala KUA ada yang menjadi fasilitator Bimbingan Pranikah yang telah terdiklat dan berhak memberikan materi-materi yang disajikan dalam Bimbingan Pranikah.

5. Kepala KUA memantau kinerja PAI Non PNS. Kepala KUA menerima laporan bulanan yang dibuat secara tertulis oleh PAI Non PNS dengan tembusan kepada Ketua POKJA/ Penyuluh Fungsional di wilayah kerjanya masing-masing.

\section{Moderasi Beragama}

Istilah moderasi (wasat, wasatiyah atau tawassuț; tawāzun, i'tidāl, ta ẩdul dan istiqāmah) adalah lawan atau kebalikan dari kata ekstrimisme dan radikalisme. Secara etimologis, moderasi berarti jalan tengah di antara dua hal atau pihak (kubu) yang berhadapan atau berlawanan (Abdilah, 2015). Wahbah alZuhayliy (t.th.; 5) mendefiniskan moderasi sebagai keseimbangan dalam keyakinan, sikap, perilaku, tatanan, muamalah dan moralitas; tidak berlebihan dalam segala perkara, tidak berlebihan dalam agama, tidak ekstrim pada keyakinan, tidak angkuh dan tidak pula lemah. Moderasi berarti sebuah pandangan atau sikap yang selalu berusaha mengambil posisi tengah dari dua sikap yang berseberangan dan berlebihan sehingga salah satu dari kedua sikap yang dimaksud tidak mendominasi dalam pikiran dan sikap seseorang (Al-Qaradāwī, 2011:13).

Singkatnya, moderasi beragama adalah cara kita beragama sesuai dengan esensi dari agama itu sendiri. Di negara-negara mayoritas muslim, sikap moderasi itu minimal meliputi pengakuan atas keberadaan pihak lain, pemilikan sikap toleran, penghormatan atas perbedaan pendapat, dan tidak memaksakan kehendak dengan cara kekerasan. Agama Islam itu moderat, tetapi cara memahami ajaran agama dapat menyebabkan seseorang tergelincir atau terperosok pada sikap ekstrem, lawan dari moderat.

\section{Analisis SWOT}

SWOT adalah singkatan dari strength (kekuatan), weakness (kelemahan), opportunity (peluang), dan threat (ancaman). SWOT adalah sebuah model dalam menganalisis suatu organisasi, baik berorientasi profit 
maupun non-profit, dengan tujuan utama untuk mengetahui keadaan organisasi tersebut secara lebih komprehensif, alat identifikasi berbagai faktor secara sistematis didasarkan pada logika yang dapat memaksimalkan kekuatan (stengths) dan peluang (opportunies), namun secara bersamaan dapat meminimalkan kelemahan (weaknesses) dan ancaman (threats) (Rangkuti, 2017:198).

Analisis SWOT ini dikenal merupakan teknik dimana para manajer menciptakan gambaran umum secara cepat mengenai situasi strategis organisasi atau perusahaan, didasarkan pada asumsi bahwa strategi yang efektif diturunkan dari "kesesuaian" yang baik antara sumber daya internal organisasi atau perusahaan (kekuatan dan kelemahan) dengan situasi eksternalnya (peluang dan ancaman) (Pearce, 2013:156). Organisasi dapat menentukan strategi setelah mengetahui kekuatan, kelemahan, peluang, dan ancaman yaitu dengan memanfaatkan kekuatan yang dimiliknya untuk mengambil keuntungan dari peluang-peluang yang ada, sekaligus memperkecil atau mengatasi kelemahan yang dimiliknya untuk menghindari ancaman yang ada (Yusuf, 2016:107).

Secara umum, ada beberapa manfaat analisis SWOT dalam mendukung menajemen pengambilan keputusan, yaitu:

1. Mampu memberikan gambaran suatu organisasi dari empat sudut dimensi yaitu strengths (kekuatan) dan weaknesses (kelemahan), serta opportunities (peluang) dan threats (ancaman). Sehingga pengambilan keputusan bisa melihat dari empat dimensi ini secara lebih komprehensif;
2. Dapat dijadikan sebagai rujukan pembuatan rencana keputusan jangka panjang;

3. Mampu memberikan pemahaman kepada stakeholders yang berkeinginan menaruh simpati bahkan bergabung dengan organisasi atau perusahaan dalam suatu ikatan kerjasama yang saling menguntungkan;

4. Dapat dijadikan penilai secara rutin dalam melihat progress report dari setiap keputusan yang telah dibuat selama ini (Fahmi, 2015:253).

Untuk melakukan analisis SWOT, diperlukan matriks SWOT yang akan membantu mempermudah merumuskan berbagai strategi yang perlu dijalankan guna memperoleh gambaran secara jelas peluang dan ancaman eksternal yang dihadapi, dan disesuaikan dengan kekuatan dan kelemahan yang dimiliknya (Kuncoro, 2005:51).

Tabel 1. Matriks SWOT

\begin{tabular}{lll}
\hline & Kekuatan & Kelemahan \\
\hline \multirow{2}{*}{ Peluang } & Strategi & Strategi WO \\
& SO & \\
Ancaman & Strategi ST & Strategi WT \\
\hline
\end{tabular}

Berikut penjelasan dari Matriks SWOT:

a. Strategi S-O (StrengthsOpportunities) Dirumuskan dengan pertimbangan bahwa manajemen hendak memanfaatkan kekuatan dan keunggulan bersaing yang dimiliki untuk mengeksploitasi peluang yang tersedia.

b. Strategi S-T (Strengths-Threats). Strategi ini lahir dari analisis manajemen yang hendak menggunakan kekuatan dan keunggulan yang dimiliki untuk menghindari efek negatif dari ancaman yang dihadapi. 
C. Strategi W-O (WeaknessesOpportunities). Strategi ini ketika manajemen mencoba memanfaatkan peluang yang tersedia untuk mengurangi bahkan mengeliminasi kelemahan organisasi yang ada.

d. Strategi W-T (WeaknessesThreats). Strategi ini pada dasarnya lebih merupakan strategi bertahan yakni strategi yang masih mungkin ditemukan dan dipilih dengan meminimalisasi kelemahan dan menghindari ancaman.

Keempat posisi dalam matriks SWOT ini menjadi bagian penting untuk memposisikan pemahaman secara lebih aplikatif karena -pada prinsipnyakonsep SWOT merupakan sebuah analisis yang dibangun secara seimbang, berkekuatan, menyatu, dan bersifat saling mendukung (Fahmi, 2015:265).

Tahapan analisis SWOT dibangun diatas kerangka formulasi strategis yang terdiri dari tiga tahapan, yakni; tahap pengumpulan data, tahap analisis, dan tahap pengambilan keputusan. Untuk lebih jelasnya dapat dilihat pada tabel di bawah ini.

Tabel 2. Kerangka Formulasi Strategis

\begin{tabular}{ll} 
1. Tahap Pengumpulan Data & \\
\hline $\begin{array}{l}\text { Evaluasi Faktor } \\
\text { Eksternal }\end{array}$ & $\begin{array}{l}\text { Evaluasi } \\
\text { Internal }\end{array}$ \\
\hline 2. Tahap Analisis Matriks SWOT & \\
\hline 3. Tahap Pengambilan \\
\hline
\end{tabular}

\section{TEMUAN DAN PEMBAHASAN}

\section{Temuan}

a. Profil Pendidikan Kepala KUA di Kabupaten Majalengka
Tabel 3. Daftar Kepala KUA di Kab. Majalengka

\begin{tabular}{|c|c|c|}
\hline \multirow[b]{2}{*}{ Kecamatan } & \multicolumn{2}{|c|}{ Daftar Kepala KUA } \\
\hline & $\begin{array}{l}\text { Nama Kepala } \\
\text { KUA }\end{array}$ & Pendidikan \\
\hline Argapura & $\begin{array}{l}\text { Drs. } \\
\text { Muhtaruddin }\end{array}$ & S1 IAIN SY 1993 \\
\hline Banjaran & $\begin{array}{l}\text { Ade Enan } \\
\text { Sudrajat, S.Ag }\end{array}$ & $\begin{array}{l}\text { S1 IAIN Dakw. } \\
1999\end{array}$ \\
\hline Bantarujeg & $\begin{array}{l}\text { H. Abd. Mukti, } \\
\text { S.Ag. }\end{array}$ & S1 STAI 2001 \\
\hline Cigasong & Idi, S.Ag. & S1 IAIN SY 1997 \\
\hline Cikijing & $\begin{array}{l}\text { Drs. H. Tata } \\
\text { Sasmita }\end{array}$ & S1 IAIN 1990 \\
\hline Cingambul & $\begin{array}{l}\text { Oo Koimudin, } \\
\text { S.Ag. }\end{array}$ & S1 IAIN SY 1997 \\
\hline Dawuan & $\begin{array}{l}\text { H. Ucu Sodikin } \\
\text { Nurjaman, S.Ag }\end{array}$ & S1 IAIN 1994 \\
\hline Jatitujuh & Drs. H. Liman & S1 IAIN SY 1991 \\
\hline Jatiwangi & $\begin{array}{l}\text { H. Wahyudin, } \\
\text { S.Ag, MA }\end{array}$ & $\begin{array}{l}\text { S2 IAIN Studi } \\
\text { Islam } 2006\end{array}$ \\
\hline Kadipaten & H. Hapid, M.Ag. & $\begin{array}{l}\text { S2 UIN Bdg } \\
2006\end{array}$ \\
\hline Kasokandel & $\begin{array}{l}\text { H. Aji Ahmad } \\
\text { Murtaji, S.Ag. }\end{array}$ & S1 STAI 2000 \\
\hline Kertajati & $\begin{array}{l}\text { Dedi Ruhaedi, } \\
\text { S.Ag }\end{array}$ & S1 IAIN SY 1997 \\
\hline Lemahsugih & $\begin{array}{l}\text { Drs. H. Nanang } \\
\text { Sudrajat }\end{array}$ & $\begin{array}{l}\text { S1 IAIN USH } \\
1990\end{array}$ \\
\hline $\begin{array}{l}\text { Leuwimundi } \\
\text { ng }\end{array}$ & $\begin{array}{l}\text { Cece moh. Ihya, } \\
\text { S.Ag }\end{array}$ & $\begin{array}{l}\text { S1 IAIN USH } \\
1993 \\
\end{array}$ \\
\hline Ligung & $\begin{array}{l}\text { Drs. H. Zaenal } \\
\text { Mutaqin }\end{array}$ & S1 IAID 1991 \\
\hline Maja & $\begin{array}{l}\text { Drs. H. Edy } \\
\text { Jubaedi } \\
\text { Abdilah }\end{array}$ & S1 IAIN SY 1991 \\
\hline Majalengka & $\begin{array}{l}\text { H. Sihabudin, } \\
\text { S.Ag, M.Ag }\end{array}$ & S2 2010 \\
\hline Malausma & $\begin{array}{l}\text { H. Koko } \\
\text { Juwaeni, S.Ag. }\end{array}$ & $\begin{array}{l}\text { S1 IAIN ADAB } \\
1996\end{array}$ \\
\hline Palasah & $\begin{array}{l}\text { Drs. H. Abd. } \\
\text { Hakim }\end{array}$ & $\begin{array}{l}\text { S1 IAIN Dakwah } \\
1988\end{array}$ \\
\hline Panyingkiran & $\begin{array}{l}\text { Amir Hamdi, } \\
\text { S.Ag }\end{array}$ & S1 IAIN SY 1998 \\
\hline Rajagaluh & $\begin{array}{l}\text { Drs. H. Wawan } \\
\text { Ridwanullah }\end{array}$ & S1 IAIC Sy. 1994 \\
\hline $\begin{array}{l}\text { Sindangwan } \\
\text { gi }\end{array}$ & $\begin{array}{l}\text { Didi Rasidi, } \\
\text { S.Ag }\end{array}$ & S1 STAI 2001 \\
\hline Sindang & Drs. ljen & S1 IAIN 1991 \\
\hline
\end{tabular}




\begin{tabular}{llc}
\hline \multirow{2}{*}{ Kecamatan } & \multicolumn{2}{c}{ Daftar Kepala KUA } \\
\cline { 2 - 3 } & $\begin{array}{l}\text { Nama Kepala } \\
\text { KUA }\end{array}$ & \multicolumn{1}{c}{ Pendidikan } \\
\hline Sukahaji & H. Kusno, S.Ag. & S1 STAI 1998 \\
\hline Sumberjaya & $\begin{array}{l}\text { H. Ansor } \\
\text { Solihin, S.HI }\end{array}$ & S1 STAI 2004 \\
\hline \multirow{2}{*}{ Talaga } & $\begin{array}{l}\text { lyan Heryandi, } \\
\text { S.Ag }\end{array}$ & S1 IAIN 1996 \\
\hline
\end{tabular}

b. Deskripsi SWOT Peran Kepala KUA dalam Membangun Moderasi beragama

1) Strength (Kekuatan)

a) Kualifikasi pendidikan dan kemampuan tertentu Kualifikasi pendidikan dan kemampuan tertentu, yakni berijazah paling rendah Sarjana S1/Diploma IV dan telah mengikuti diklat fungsional kepenghuluan dan memperoleh STTPP (Surat Tanda Tamat Pendidikan dan Pelatihan).

b) Otoritas sebagai kepala kantor dan wakil pemerintah. Kantor Urusan Agama adalah Unit Pelaksana Teknis Direktorat Jenderal Bimbingan Masyarakat Islam yang bertugas melaksanakan sebagian tugas Kantor Kementerian Agama Kabupaten/Kota di bidang urusan agama Islam.

c) Peran pemimpin. Kepala KUA mempunyai tugas memimpin, mengorganisasikan, melaksanakan, dan melaporkan pelaksanaan tugas dan fungsi KUA kepada Kepala Kantor Kementerian Agama Kabupaten/Kota.

d) Bidang kajian. meliputi pengkajian masalah hukum munakahat, bahthu al-masā'il munakahat dan ahwal alshakhshiyah.

e) Fasilitator Bimbingan Pranikah dan berhak memberikan materi- materi yang disajikan dalam Bimbingan Perkawinan Pranikah.

f) Kepala KUA memantau kinerja PAI Non PNS.

g) Kepala KUA memiliki peran ganda. Sebagian kepala KUA ada yang menjadi pimpinan pondok pesantren, ketua MUI kecamatan, dan ketua ormas Islam.

2) Weakness (Kelemahan)

a) Penghulu atau KUA adalah pelaksana teknis Direktorat Jenderal Bimbingan Masyarakat Islam yang bertugas melaksanakan sebagian tugas Kantor Kementerian Agama Kabupaten/Kota di bidang urusan agama Islam.

b) Terlalu mengandalkan otoritas untuk memperoleh dukungan dan memiliki pengaruh, padahal, ada sumber pengaruh lain yang lebih tinggi dari otoritas, yakni keteladanan, kemampuan memotivasi, mementoring, dan melipatgandakan.

c) Jarang melakukan pengkajian terkait moderasi beragama. Secara institusional atau organisasional, penghulu atau kepala KUA jarang melakukan pengkajian bersama tentang soal-soal aktual yang berkenaan dengan munakahat, ahwal alshakhshiyah, muamalah, dan hukum Islam secara umum.

d) Konsep diri yang lemah. Konsep diri ini terkait langsung dengan informasi, pengetahuan, dan keahlian. Dengan bertambahnya informasi, pengetahuan, dan keahlian secara otomatis akan meningkatkan citra diri, konsep diri, kepercayaan diri, dan lainlain. 
e) Tidak menyadari bahwa ia telah melakukan upaya moderasi dalam moderasi beragama. Fokus perhatiannya tertuju pada apa yang dilakukannya "sebatas" pelaksanaan tugas semata.

3) Opportunity (Peluang)

a) Koordinasi kegiatan lintas sektoral dibidang nikah dan rujuk, baik dalam lingkungan KUA maupun dalam hubungan antar pemerintah, baik pusat maupun daerah.

b) Kepala KUA memiliki peran komandan yang bertanggung jawab untuk memimpin, mengorganisasikan, dan mengkoordinasikan pelaksanaan tugas bawahan.

c) Kepala KUA memiliki peran guru, baik pelaporan administrasi keuangan, akuntansi, maupun pelaporan kinerja sesuai ketentuan peraturan perundangundangan.

d) Kepala KUA memiliki peran bapak dalam menjalankan pengawasan melekat, penilaian kinerja, mematuhi ketentuan peraturan perundang-undangan dan menyampaikan pelaporan hasil pelaksanaan tugasnya kepada atasan masing-masing secara berjenjang dan berkala.

e) Pelayanan fatwa hukum munakahat dan bimbingan muamalah dan hukum Islam.

f) Pengembangan profesi seperti menyusunan karya tulis ilmiah di bidang hukum Islam; penerjemahan atau penyaduran buku dan karya ilmiah di bidang kepenghuluan dan hukum Islam; pelayanan konsultasi kepenghuluan dan hukum Islam. g) Penyusunan kompilasi fatwa hukum munakat, bahth al-masā'il munakahat dan ahwāl alshakhshiyah.

h) Karakteristik penting moderasi hukum Islam seperti a) Dapat menerima perubahan atau pembaruan; b) Hukum Islam memberikan kemudahan; c) Bila ada kesulitan, ada Rukhshat, dan; d) Membebankan hukum secara bertahap.

i) Hukum Islam berbentuk qānūn yang bersifat mengikat dan memaksa.

j) Media sosialisasi dan persuasi melalui berbagai media yang dapat dilakukan seperti pada ceramah pengajian, khutbah Jumat, atau berbagai kegiatan lintas sektoral lainnya.

4) Threath (Hambatan)

a) Fanatisme mazhab yang tidak membenarkan berpindah mazhab.

b) Intoleransi dan radikalisme yang tidak menghargai perbedaan agama, suku, etnis, pendapat, sikap, dan tindakan orang lain yang berbeda dengan dirinya dan menggunakan cara-cara kekerasan.

c) Moderasi dianggap indikasi inkonsistensi dalam memegang teguh agama.

d) Persuasi yang tidak intens, hanya sebatas seremonial. Padahal untuk membangun moderasi dalam beragama dibutuhkan upaya-upaya yang intens, berkelanjutan, dan tidak hanya sebatas seremonial.

e) Pengaruh ulama tertentu yang sangat kuat. 


\section{Pembahasan}

a. Analisis Data Matriks SWOT Kepala KUA dalam Membangun Moderasi Beragama di Kabupaten Majalengka

Sebelum membuat matriks faktor strategi internal dan eksternal, terlebih dahulu dibuat Internal Factor Analysis Summary (IFAS) sebagai berikut:

Tabel 4. Internal Factor Analysis Summary (IFAS)

\begin{tabular}{|c|c|c|c|c|}
\hline $\begin{array}{c}\text { Faktor-Faktor } \\
\text { Strategi Internal }\end{array}$ & Nilai & Bobot & Rating & Skor \\
\hline \multicolumn{5}{|l|}{ Strength $(\mathbf{S})$} \\
\hline $\begin{array}{l}\text { Kualifikasi } \\
\text { pendidikan dan } \\
\text { kemampuan } \\
\end{array}$ & 3 & 0,15 & 4 & 0,60 \\
\hline $\begin{array}{l}\text { Otoritas } \\
\text { sebagai kepala } \\
\text { kantor dan } \\
\text { wakil } \\
\text { pemerintah }\end{array}$ & 1 & 0,05 & 3 & 0,15 \\
\hline $\begin{array}{l}\text { Peran } \\
\text { pemimpin }\end{array}$ & 2 & 0,10 & 2 & 0,20 \\
\hline $\begin{array}{l}\text { Bidang kajian } \\
\text { yang luas }\end{array}$ & 1 & 0,05 & 2 & 0,10 \\
\hline $\begin{array}{l}\text { Fasilitator } \\
\text { Bimbingan } \\
\text { Pranikah }\end{array}$ & 1 & 0,05 & 1 & 0,05 \\
\hline $\begin{array}{l}\text { Kepala KUA } \\
\text { memantau } \\
\text { kinerja PAI Non } \\
\text { PNS }\end{array}$ & 1 & 0,05 & 1 & 0,05 \\
\hline $\begin{array}{l}\text { Kepala KUA } \\
\text { memiliki peran } \\
\text { ganda }\end{array}$ & 1 & 0,05 & 1 & 0,05 \\
\hline Sub Total & & 0,50 & & 1,20 \\
\hline \multicolumn{5}{|l|}{ Weakness (W) } \\
\hline $\begin{array}{l}\text { KUA adalah } \\
\text { pelaksana } \\
\text { teknis }\end{array}$ & 2 & 0,10 & 1 & 0,10 \\
\hline $\begin{array}{l}\text { Penghulu } \\
\text { adalah } \\
\text { pelaksana } \\
\text { teknis }\end{array}$ & 2 & 0,10 & I & 0,10 \\
\hline $\begin{array}{l}\text { Terlalu } \\
\text { mengandalkan } \\
\text { otoritas }\end{array}$ & 2 & 0,10 & 2 & 0,20 \\
\hline
\end{tabular}

\begin{tabular}{lcccc}
\hline $\begin{array}{l}\text { Jarang } \\
\text { melakukan } \\
\text { pengkajian } \\
\text { hukum }\end{array}$ & 2 & 0,10 & 3 & 0,30 \\
\hline $\begin{array}{l}\text { Konsep diri } \\
\text { yang lemah }\end{array}$ & 1 & 0,05 & 4 & 0,20 \\
\hline $\begin{array}{l}\text { Tidak } \\
\text { menyadari } \\
\text { bahwa ia telah } \\
\text { melakukan }\end{array}$ & 1 & 0,05 & 4 & 0,20 \\
$\begin{array}{l}\text { upaya } \\
\text { moderasi } \\
\text { dalam } \\
\text { beragama }\end{array}$ & & & & \\
\hline Sub Total & 0,50 & & 1,10 \\
\hline Total & 20 & 1,00 & 29 & 2,30 \\
\hline
\end{tabular}

Sedangkan External Factor Analysis Summary (EFAS) dengan cara yang sama dengan IFAS hanya saja kekuatan diganti dengan peluang dan kelemahan diganti dengan hambatan, sebagai berikut:

Tabel 5. External Factor Analysis Summary (EFAS)

\begin{tabular}{lllll}
\hline $\begin{array}{l}\text { Faktor-Faktor } \\
\text { Strategi } \\
\text { Internal }\end{array}$ & Nilai & Bobot Rating & Skor \\
\hline $\begin{array}{l}\text { Opportunies } \\
\text { (O) }\end{array}$ & & & & \\
\hline $\begin{array}{l}\text { Koordinasi } \\
\text { lintas sektoral } \\
\text { di bidang } \\
\text { nikah dan }\end{array}$ & 3 & 0,15 & 4 & 0,60 \\
rujuk & & & & \\
\hline $\begin{array}{l}\text { Pelayanan } \\
\text { fatwa hukum } \\
\text { munakahat } \\
\text { dan }\end{array}$ & & & & \\
$\begin{array}{l}\text { bimbingan } \\
\text { muamalah } \\
\text { dan hukum }\end{array}$ & 2 & 0,10 & 4 & 0,40 \\
\begin{tabular}{l} 
Islam. \\
\hline $\begin{array}{l}\text { Pengembang } \\
\text { an profesi }\end{array}$
\end{tabular} & 2 & 0,10 & 4 & 0,40 \\
\hline $\begin{array}{l}\text { Penyusunan } \\
\text { kompilasi } \\
\text { fatwa hukum } \\
\text { munakat }\end{array}$ & 2 & 0,10 & 3 & 0,30 \\
\hline & & & & \\
\hline
\end{tabular}




\begin{tabular}{lllll}
\hline $\begin{array}{l}\text { Karakteristik } \\
\text { penting } \\
\text { mode }\end{array}$ & 1 & 0,05 & 3 & 0,15 \\
$\begin{array}{l}\text { rasi } \\
\text { beragama }\end{array}$ & & & & \\
\hline $\begin{array}{l}\text { Hukum Islam } \\
\text { berben } \\
\text { tuk qānūn }\end{array}$ & 1 & 0,05 & 3 & 0,15 \\
\hline $\begin{array}{l}\text { Media } \\
\text { sosialisasi } \\
\text { dan persuasi }\end{array}$ & 1 & 0,05 & 2 & 0,10 \\
\hline $\begin{array}{l}\text { Sub Total } \\
\text { Threath (T) }\end{array}$ & 0,60 & & 2,10 \\
\hline $\begin{array}{l}\text { Fanatisme } \\
\text { mazhab }\end{array}$ & 3 & 0,15 & 1 & 0,15 \\
\hline $\begin{array}{l}\text { Intoleransi } \\
\text { dan } \\
\text { radikalisme }\end{array}$ & 2 & 0,10 & 1 & 0,10 \\
\hline $\begin{array}{l}\text { Modera } \\
\text { si dianggap } \\
\text { indikasi } \\
\text { inkonsistensi }\end{array}$ & 1 & 0,05 & 2 & 0,05 \\
\hline $\begin{array}{l}\text { Persuasi tidak } \\
\text { intens, hanya } \\
\text { sebatas } \\
\text { seremonial }\end{array}$ & 1 & 0,05 & 2 & 0,10 \\
\hline $\begin{array}{l}\text { Pengaruh } \\
\text { ulama } \\
\text { tertentu yang } \\
\text { sangat kuat }\end{array}$ & 1 & 0,05 & 1 & 0,05 \\
\hline $\begin{array}{l}\text { Sub Total } \\
\begin{array}{l}\text { Total } \\
\hline\end{array}\end{array}$ & 0,40 & & 0,65 \\
\hline
\end{tabular}

Setelah mengevaluasi faktor strategis di atas, selanjutnya kita dapat melihat kuadran IFE-EFE untuk menentukan penilaian posisi peran kepala KUA dalam membangun moderasi beragama di Kabupaten Majalengka. Penilaian hasil evaluasi faktor internal (IFE) adalah sebesar 2,30 dan faktor eksternal adalah sebesar 2,75. Nilai ini berada pada kuadran V berwarna kuning yaitu "jaga dan pertahankan". Keberadaan posisi pada fase ini menunjukkan bahwa peran kepala KUA dalam membangun beragama di Kabupaten Majalengka sudah relatif baik dan harus dipertahankan karena mempunyai potensi yang sangat besar untuk kemaslahatan publik. Keberadaan faktor-faktor internal dan eksternal pada dasarnya menjadi dukungan yang sangat besar bagi peran kepala KUA.

Tabel 6. Kuadran Matriks IFE EFE

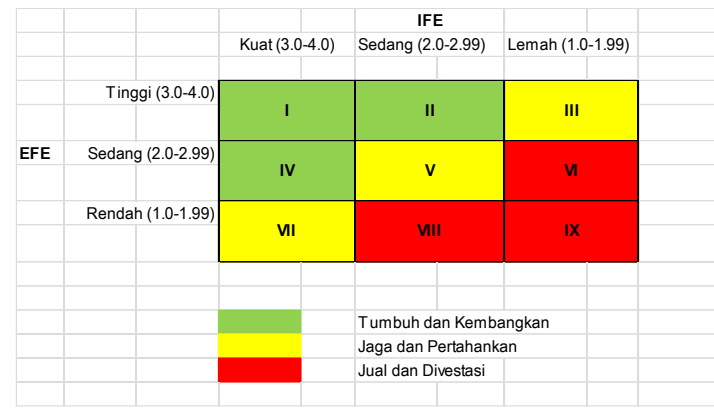

b. Pengambilan Keputusan Peran Kepala KUA dalam Membangun Moderasi Beragama di Kabupaten Majalengka

Perumusan alternatif strategi pengembangan peran kepala KUA dalam membangun moderasi beragama di Kabupaten Majalengka dengan analisis SWOT merupakan gabungan antara faktor internal (kekuatan dan kelemahan). Berdasarkan faktor kekuatan, kelemahan, peluang dan ancaman yang telah teridentifikasi, maka melalui analisis SWOT dapat dirumuskan 13 alternatif strategi pengembangan peran kepala KUA dalam membangun moderasi beragama di Kabupaten Majalengka.

Setelah disusun tabel IFAS dan EFAS, maka transfer peluang dan ancaman dari tabel EFAS serta ditambahkan kekuatan dan kelemahan dari tabel IFAS kedalam sel yang sesuai dalam matriks TOWS. Matrik ini dapat menghasilkan empat sel kemungkinan strategi alternatif, sebagai berikut: 
Tabel 7. Matriks SWOT

\begin{tabular}{|c|c|c|}
\hline \multirow{3}{*}{ EFAS } & \multicolumn{2}{|c|}{ IFAS } \\
\hline & Strengths & Weakness \\
\hline & $\begin{array}{l}\text { Kualifikasi } \\
\text { pendidikan } \\
\text { dan } \\
\text { kemampuan }\end{array}$ & $\begin{array}{l}\text { KUA adalah } \\
\text { pelaksana } \\
\text { teknis }\end{array}$ \\
\hline & $\begin{array}{l}\text { Otoritas } \\
\text { sebagai } \\
\text { kepala kantor } \\
\text { dan wakil } \\
\text { pemerintah }\end{array}$ & $\begin{array}{l}\text { Penghulu } \\
\text { adalah } \\
\text { pelaksana } \\
\text { teknis }\end{array}$ \\
\hline & $\begin{array}{l}\text { Peran } \\
\text { pemimpin }\end{array}$ & $\begin{array}{l}\text { Terlalu } \\
\text { mengandalka } \\
\text { n otoritas }\end{array}$ \\
\hline & $\begin{array}{l}\text { Bidang kajian } \\
\text { yang luas }\end{array}$ & $\begin{array}{l}\text { Jarang } \\
\text { melakukan } \\
\text { pengkajian } \\
\text { hukum }\end{array}$ \\
\hline & $\begin{array}{l}\text { Fasilitator } \\
\text { bimbingan } \\
\text { pranikah }\end{array}$ & $\begin{array}{l}\text { Konsep diri } \\
\text { yang lemah }\end{array}$ \\
\hline & $\begin{array}{l}\text { Kepala KUA } \\
\text { memantau } \\
\text { kinerja PAI } \\
\text { Non PNS }\end{array}$ & $\begin{array}{l}\text { Tidak } \\
\text { menyadari } \\
\text { bahwa ia } \\
\text { telah } \\
\text { melakukan } \\
\text { upaya } \\
\text { moderasi } \\
\text { dalam } \\
\text { hukum Islam }\end{array}$ \\
\hline & $\begin{array}{l}\text { Kepala KUA } \\
\text { memiliki } \\
\text { peran ganda }\end{array}$ & \\
\hline $\begin{array}{l}\text { Opportunity } \\
\text { (O) }\end{array}$ & Strategi SO & Strategi WO \\
\hline $\begin{array}{l}\text { Koordinasi } \\
\text { kegiatan } \\
\text { lintas } \\
\text { sektoral } \\
\text { dibidang } \\
\text { nikah dan } \\
\text { rujuk }\end{array}$ & $\begin{array}{l}\text { Mengoptimal } \\
\text { kan peran } \\
\text { Kepala KUA }\end{array}$ & $\begin{array}{l}\text { Meningkat- } \\
\text { kan } \\
\text { kemampuan } \\
\text { persuasi }\end{array}$ \\
\hline $\begin{array}{l}\text { Pelayanan } \\
\text { fatwa hukum } \\
\text { munakahat } \\
\text { dan } \\
\text { bimbingan } \\
\text { muamalah } \\
\text { dan hukum }\end{array}$ & $\begin{array}{l}\text { Meningkat- } \\
\text { kan } \\
\text { kualifikasi } \\
\text { dan } \\
\text { kemampuan } \\
\text { dalam kajian } \\
\text { hukum Islam }\end{array}$ & $\begin{array}{l}\text { Meningkat- } \\
\text { kan kajian- } \\
\text { kajian hukum } \\
\text { Islam dan } \\
\text { keagamaan }\end{array}$ \\
\hline
\end{tabular}

\begin{tabular}{|c|c|c|}
\hline \multirow{2}{*}{ EFAS } & \multicolumn{2}{|c|}{ IFAS } \\
\hline & Strengths & Weakness \\
\hline Islam. & $\begin{array}{l}\text { dan } \\
\text { keagamaan }\end{array}$ & \\
\hline $\begin{array}{l}\text { Pengenmban } \\
\text { gan profesi }\end{array}$ & $\begin{array}{l}\text { Memanfaatk } \\
\text { an semua } \\
\text { media, baik } \\
\text { internal } \\
\text { maupun } \\
\text { lintas } \\
\text { sektoral, baik } \\
\text { personal } \\
\text { maupun } \\
\text { institusional. }\end{array}$ & $\begin{array}{l}\text { Membangun } \\
\text { konsep diri } \\
\text { yang baik }\end{array}$ \\
\hline $\begin{array}{l}\text { Penyusunan } \\
\text { fatwa hukum } \\
\text { munakahat }\end{array}$ & & $\begin{array}{l}\text { Membangun } \\
\text { kesadaran } \\
\text { bahwa } \\
\text { pelaksanaan } \\
\text { tugas-tugas } \\
\text { teknis tidak } \\
\text { dapat } \\
\text { dilepaskan } \\
\text { dari upaya- } \\
\text { upaya ijtihadi }\end{array}$ \\
\hline $\begin{array}{l}\text { Karakteristik } \\
\text { penting } \\
\text { moderasi } \\
\text { hukum Islam }\end{array}$ & & \\
\hline $\begin{array}{l}\text { Hukum Islam } \\
\text { berbentuk } \\
\text { qânûn }\end{array}$ & & \\
\hline $\begin{array}{l}\text { Media } \\
\text { sosialisasi } \\
\text { dan persuasi } \\
\end{array}$ & & \\
\hline Threath (T) & Strategi ST & Strategi WT \\
\hline $\begin{array}{l}\text { Fanatisme } \\
\text { madzhab }\end{array}$ & $\begin{array}{l}\text { Meningkatka } \\
\mathrm{n} \text { kerja sama } \\
\text { lintas } \\
\text { sectoral }\end{array}$ & $\begin{array}{l}\text { Membangun } \\
\text { konsep diri } \\
\text { yang baik }\end{array}$ \\
\hline $\begin{array}{l}\text { Intoleransi } \\
\text { dan } \\
\text { radikalisme }\end{array}$ & $\begin{array}{l}\text { Melakukan } \\
\text { sosialisasi } \\
\text { dan edukasi } \\
\text { kepada } \\
\text { masyarakat }\end{array}$ & $\begin{array}{l}\text { Meningkatka } \\
\mathrm{n} \\
\text { kemampuan } \\
\text { persuasi }\end{array}$ \\
\hline $\begin{array}{l}\text { Moderasi } \\
\text { dianggap } \\
\text { indikasi } \\
\text { inkonsistensi }\end{array}$ & $\begin{array}{l}\text { Meningkatka } \\
\mathrm{n} \\
\text { kemampuan } \\
\text { persuasi }\end{array}$ & $\begin{array}{l}\text { Meningkatka } \\
\text { n kajian- } \\
\text { kajian hukum } \\
\text { Islam dan } \\
\text { keagamaan }\end{array}$ \\
\hline
\end{tabular}




\begin{tabular}{|c|c|c|}
\hline \multirow{2}{*}{ EFAS } & \multicolumn{2}{|c|}{ IFAS } \\
\hline & Strengths & Weakness \\
\hline $\begin{array}{l}\text { tidak intens, } \\
\text { hanya } \\
\text { sebatas } \\
\text { seremonial }\end{array}$ & & \\
\hline $\begin{array}{l}\text { Pengaruh } \\
\text { ulama }\end{array}$ & & \\
\hline
\end{tabular}

\section{PENUTUP}

\section{Simpulan}

Berdasarkan hasil kajian penulis mengenai Analisis SWOT Peran Kepala KUA dalam membangun moderasi beragama di Kabupaten Majalengka, maka penulis mengambil kesimpulan bahwa terdapat beberapa alternatif strategi yang dapat digunakan sesuai dengan pertimbangan kombinasi empat set faktor strategi, yakni:

a. Strategi SO (mendukung strategi agresif), yaitu dengan mengoptimalkan peran Kepala KUA, meningkatkan kualifikasi dan kemampuan dalam kajian keagamaan, dan memanfaatkan semua media, baik internal maupun lintas sektoral, baik personal maupun institusional.

b. Strategi ST (mendukung strategi diversifikasi), yaitu dengan meningkatkan kerja sama lintas sektoral, melakukan sosialisasi dan edukasi kepada masyarakat, dan meningkatkan kemampuan persuasi.

c. Strategi WO (mendukung strategi turn-around), yaitu dengan meningkatkan kemampuan persuasi, meningkatkan kajian-kajian keagamaan, membangun konsep diri yang baik, dan membangun kesadaran bahwa pelaksanaan tugas-tugas teknis tidak dapat dilepaskan dari upaya-upaya ijtihadi.

d. Strategi WT (mendukung strategi defensif), yaitu dengan membangun

\begin{tabular}{|c|c|c|}
\hline \multirow{2}{*}{ EFAS } & \multicolumn{2}{|c|}{ IFAS } \\
\hline & Strengths & Weakness \\
\hline $\begin{array}{l}\text { tertentu yang } \\
\text { sangat kuat }\end{array}$ & & \\
\hline
\end{tabular}

konsep diri yang baik, meningkatkan kemampuan persuasi, dan meningkatkan kajian-kajian keagamaan.

e. Berdasarkan hasil IFAS-EFAS, diketahui bahwa peran kepala KUA dalam membangun moderasi beragama di Kabupaten Majalengka sudah relatif baik dan harus dipertahankan karena mempunyai potensi yang sangat besar untuk kemaslahatan publik. Keberadaan faktor-faktor internal dan eksternal pada dasarnya menjadi dukungan yang sangat besar bagi peran kepala KUA.

\section{Rekomendasi}

Berdasarkan simpulan pembahasan yang telah diuraikan, perlu dikemukakan bahwa Kepala KUA memiliki peran penting dalam membangun moderasi beragama di Kabupaten Majalengka. Sebagai rekomendasi penulisan ini, dapat dikemukakan hal sebagai berikut:

a. Untuk Kepala KUA, yaitu memaksimalkan perannya dalam membangun moderasi beragama di Kabupaten Majalengka;

b. Untuk Kepala Kemenag Kabupaten Majalengka, yaitu meningkatkan kualifikasi keilmuan dan keterampilan Kepala KUA sehingga terbangun konsep diri yang baik.

c. Untuk pengkaji berikutnya, penelitian ini jauh dari sempurna maka butuh untuk disempurnakan lagi. 
d. Berdasarkan peta matriks, peran kepala KUA dalam membangun moderasi beragama di Kabupaten Majalengka harus lebih disosialisasikan secara lebih masif dan terstruktur agar lebih memberikan pemahaman yang komprehensif terhadap seluruh kalangan dan publik secara umum, dalam kerangka kemaslahatan yang lebih besar dan luas.

\section{DAFTAR PUSTAKA}

Abdillah, Masykuri. (2015, Februari 9). Meneguhkan Moderasi Beragama. Dipetik dari http://graduate.uinjkt.ac.id/?p=17325.

Al-Qarḍawī, Yūsuf. (2011). Kalimah fĩ al-Wasațīyah wa Madlīmihā. Qāhirah; Dār al-Shurūq Al-Zuhaylī, Wahbah. t.th. Al-Wasațīyah Mațlab Shar ‘̄ wa Hadarī. t.p;

Ali, Imam Shamsi. (2017, Mei 6). Memahami Moderasi Dalam Beragama. Dipetik 19 Februari 2019 dari https://republika.co.id/berita/jurnalismewarga/wacana/17/05/05/opgnlt396-memahami-moderas Republika.co.id

Assauri, Sofjan. (2016). Strategic Management: Sustainable Competitive Advantages. Jakarta; Rajawali Pers

Athorida, Aang. (2010). Ormas-Ormas Keagamaan di Indonesia. Bekasi; Pijar,

Bangkit, Widarko. (2015). Jadikan dirimu orang yang tak terlupakan. Jakarta; Laksana

Dahlan, Moh. (2016). Moderasi Hukum Islam dalam Pemikiran Ahmad Hasyim Muzadi. AlIhkam, 11 (2) Desember 2016. Bengkulu; Pascasarjana IAIN Bengkulu, 2016 hal. 323.

Fahmi, Irham. (2015). Manajemen Strategis: Teori dan Aplikasi. Bandung; Alfabeta

Gunawan, Imam. (2015). Metode Penelitian Kualitatif: Teori dan Praktik. Jakarta; Bumi Aksara

Handjoko. (2009). Jalan Emas; Langkah-Langkah Kritis Menuju Puuncak Prestasi. Jakarta; Elex Media Komputindo

Indrawan, Rully dan Poppy Yaniawati. (2016). Metodologi Penelitian Kuantitatif, Kualitatif, dan Campuran. Bandung; Refika Aditama

Kuncoro, Mudrajad. (2005). Strategi : Bagaimana Meraih Keunggulan Kompetitif. Jakarta; ERLANGGA

Moleong, Lexy J. (2011). Metode Penelitian Kualitatif. Bandung; Remaja Rosdakarya

Muhammad, Suwarsono. (2013). Manajemen Stratejik: Konsep dan Alat Analisis. Yogyakarta; UPP STIM YKPN

Nata, Abuddin. Islam Rahmatan lil Alamin Sebagai Model Pendidikan Islam Memasuki Asean Community. Dipetik 12 November 2016 dari http://fitk.uinmalang.ac.id/sites/default/files/materi/Materi\%20Kuliah\%20Tamu\%20PAI\%202016_.p df. 
Pearce, Jhon A. dan Richard B. Robinson. (2013). Manajemen Strategis: Formulasi, Implementasi, dan Pengendalian. Jakarta; Salemba Empat

PER/62/M.PAN/6/2005 Tentang Jabatan Fungsional Penghulu dan Angka Kreditnya.

PERMENPAN RB RI Nomor 9 Tahun 2019 tentang Jabatan Fungsional Penghulu.

PMA Nomor 19 tahun 2018 tentang Pencatatan Perkawinan

PMA Nomor: 39 tahun 2012 tentang Organisasi Tata Kerja Kantor Urusan Agama.

Rahman, Agus Abdul. (2017). Psikologi Sosial. Jakarta; Rajawali Press

Rangkuti, Freddy. (2013). Analisis SWOT: Teknik Membedah Kasus Bisnis. Jakarta: Gramedia Pustaka

Rangkuti, Freddy.(2017). SWOT Balanced Scorecard. Jakarta; Gramedia Pustaka Utama

Rasyid, Hamdan. (2009). Pesona Kesempurnaan Islam. Jakarta; Zahira Press

Siagian, Sondang P. (2012). Manajemen Stratejik. Jakarta; Bumi Aksara

Sugiyono. (2016). Metode Penelitian Kuantitatif, Kualitatif dan R\&D. Bandung; Alfabeta

Ubaedy, AN. (2010). Jangan Cuma Berserah Diri. Jakarta; Sakanta

Umar, Husein. (2013). Metode Penelitian untuk Skripsi dan Tesis Bisnis. Jakarta: Rajawali Pers

Yusuf, Arif. (2016). Pemahaman Strategi Bisnis dan Kewirausahaan. Jakarta; Kencana 